\title{
THE ROLE OF DOMENICO DE VIVO IN DEVELOPING RUSSIAN AND ITALIAN LANGUAGE STUDIES IN THE SECOND HALF OF 19TH CENTURY
}

Domenico De Vivo (1839-1897) was an Italian scholar, who taught Russian and English in Italy and Italian in Russia, but is best known for his Italian-Russian Dictionary (De Vivo, Dizionario [1894]). De Vivo also published the first Russian grammar book to be written in Italian (De Vivo, Grammatica [1882]) and could be considered the forefather of Russian studies in Italy. Unfortunately, after he emigrated to the Russian Empire, his name has practically disappeared from Italian and Russian studies for more than a century. While researching his life and works, I was able to access never previously studied archival sources in Italy, Ukraine and the Russian Federation. Hopefully this research will lead to De Vivo being rightfully acknowledged for his importance in the history of Nineteenth Century Russian and Italian language studies (On this topic, see: Cifariello, "O pervoy"; "Domenico De Vivo"; "L'insegnamento"; "La grammaticografia").

During the 1860s De Vivo attended the Faculty of Literature and Philosophy at the Royal University of Naples (RUN) (ДАОО*, f. 45 о. 8 s. 16 (1896): De Vivo's personal file, 302), where he met Giacomo Lignana

Alessandro Cifariello, PhD - the Tuscia University in Viterbo, Italy, Department of Linguistic, Literary, Philosophico-Historical and Juridical Studies (DISTU), Tenure Track Researcher; e-mail: a.cifariello@unitus.it; ORCID: https://orcid.org/0000-0002-4341-0902.

*ARCHIVES:

Archivio Benedetto Croce (Benedetto Croce Archive, Biblioteca Benedetto Croce Foundation, Naples) (hereafter ABC).

Archivio Centrale dello Stato, Ministero della Pubblica Istruzione (The Italian State Central Archives, Minister of Public Education) (hereafter ACS-MPI).

Biblioteca Nazionale Centrale di Firenze (National Central Library of Florence) (hereafter BNC-F). Derzhavnyy arkhiv Odes'koyi oblasti [Державний архів Одеської області] (The State Archive of

Odessa oblast') (hereafter ДАОО). 
(1827-1891), who taught Linguistics at RUN from 1861 until 1871. De Vivo also played an important role assisting Lignana at his school of Comparative Linguistics at RUN (BNC-F, M. Kerbaker and A. De Gubernatis Correspondence: De Gubernatis' collection, c. 71 n. 1, 113 letters (1865-1909), 5: Naples, 28.01.1868; BNC-F, G. Lignana and A. De Gubernatis correspondence: De Gubernatis' collection, c. 76 n. 15, 15 letters (1865-1888), 9: Naples, 11.09.1868; see also: Croce 71). From 1868 until 1870 De Vivo worked as professor of Russian and English in the Lay School of Living Oriental Languages (LSLOL) at the Royal Asiatic College (RAC), directed by Lignana. He also generally supervised the didactics of modern foreign language (MFL) teaching (see: Fatica, "Giacomo Lignana" 187, and "Breve storia" 244-245).

The LSLOL at RAC was part of Lignana's more complex and never fully realized project - involving both RAC and RUN - to reform L2 teaching. According to his concept of opposing theoretical and practical language learning, Lignana planned to divide linguistic subjects into "preliminary and genetic subjects" at RUN with a comparative-historical approach, and "practical subjects" at RAC with a practical approach in L2 teaching (Lignana 2728). As part of his plans Lignana probably intended to appoint De Vivo at RUN as professor of Russian with a comparative-historical approach, and at RAC as professor of Russian with a practical approach. This fact partially explains why in 1870 De Vivo chose to leave Naples for Russia at the end of his second year at RAC. He settled in St. Petersburg, where he could improve his knowledge of the Russian language, experience new approaches in teaching Russian as L2, and meet the foremost representatives of the Imperial Academy of Science. The acquired knowledge, contacts and material would prepare him for the positions to be offered by Lignana. However, as a result of Lignana's decision to leave RAC permanently, the courses at RAC had to be suspended until a new director was appointed.

In 1874 De Vivo returned to Naples, where he formally requested that the RAC board reappoint him to his previous (and still vacant) Russian language teaching position (ACS-MPI, Personnel's cabinet, 1860-1880: $1^{\text {st }}$ deposit, De Vivo's personal file, Petition to the Ministry of Public Education, 26.04. 1874). However, despite his hopes, he never received a final decision from the ministerial commission. From 1876 to 1878 he taught Russian at the Philological Circle in Naples (PCN) (ACS-MPI, Personnel's cabinet, 18601880: $1^{\text {st }}$ deposit, De Vivo's personal file). In 1878 the Minister of Education drafted a series of decrees in order to reform RAC (28.10.1878, n. 4606; 
28.10 .1878$, n. $4607 ; 8.12 .1878$, n. $4671 ; 8.12 .1878$, n. 4672). The royal decrees listed eight languages that could possibly be taught at RAC university-level courses, but did not include Russian. At the same time De Vivo's Russian language lectures at PCN were suspended. By this point thoroughly disillusioned, he decided to leave Italy and move to the Russian Empire once and for all. On $15^{\text {th }}$ February 1879 he was officially appointed lecturer of Italian language at the Imperial University of Dorpat (currently Tartu, Estonia) (Spisok lits 753), holding the position until 1883 (ДАОО, f. 45 o. 8 s. 16 (1896): De Vivo's personal file, 300). At the beginning of 1884 he was appointed lector of Italian language at the New Russia Imperial University in Odessa (currently Odessa I.I. Mechnikov National University, Ukraine). He also worked as an Italian teacher at both the Odessa Commercial High School and the Odessa branch of the Imperial Russia Music society from 21 $1^{\text {st }}$ November 1884 (See: Istoricheskiy ocherk 15; Varvartsev 97). On $28^{\text {th }}$ December 1896 (10 ${ }^{\text {th }}$ January 1897, New Style) De Vivo died in Odessa (ДАОО, f. 45 o. 8 s. 16 (1896): De Vivo's personal file, 314-317, 323-324).

Published in Dorpat in 1882, De Vivo's Grammatica della lingua russa [Russian Grammar for Italians] was the first Russian grammar book in Italian and remained the sole example until the 1897 publication of Voinovich's grammar book (Grammatica della lingua russa). The first manuscript of Russian Grammar for Italians dates back to 1875 and 1876, which is the period between his appointments at RAC and his lectures at PCN (ACS-MPI, Personnel's cabinet, 1860-1880: $1^{\text {st }}$ deposit, De Vivo's personal file, gen. ref. n. 47996, 14.12.1876; gen. ref. n. 3376, 19.12.1876). The reference sources quoted in Russian Grammar for Italians were published between 1828 and 1876 (Gretsch and Reiff; Pavskiy; Vostokov; Buslaev, Istoricheskaya grammatika [1875]; Grot). De Vivo's text must therefore date back to the years 1876-1878, before he decided to leave Italy definitively. The fact that Italian was chosen as the language for publication indicates that the book was written with Italian learners in mind. Furthermore, the book's structure demonstrates that it was intended as a support for teaching purposes, yet with a more theoretical exposition than the practical textbook then in use at RAC - Paul Fuchs's Russian grammar book with key-book (ABC, correspondence, 1892, n. 85, G. De Vincentiis to B. Croce, 9.03.1892, 1-9).

In 1882 De Vivo also published his Del futuro e del condizionale nell' Italiano in rapporto colle altre lingue romanze [Essay on Future and Conditional tenses of the Italian Language Compared with the Same Tenses 
of the other Romance Languages]. From the point of view of Comparative Linguistics the author observes and compares the suffixes of the future and the conditional tenses of the Romance languages, Italian dialects, and Latin. From the sources that the author often quotes in the footnotes, the period in which the essay was written can be deduced. The reference bibliography consists of works published between 1814 and 1868. Since the essay's most recent source dates back to 1868 , when De Vivo collaborated with Lignana at RUN and was appointed English and Russian professor at RAC, and also considering the fact that the subject of the essay is a typical subject of Lignana's philological classes at RUN, it can be said with certainty that this work belongs to De Vivo's period at RAC and RUN, probably comprising his notes as a scholar during the 1860 s, reworked and completed with some other bibliographic sources.

In 1886 his first Italian textbook for Russian students - Prakticheskoe rukovodstvo dlya izucheniya ital'yanskogo yazyka [A Practical Guide to Learning Italian] - was published. This work was submitted to the Censorship Bureau in 1884 and approved in January 1885. This long publishing process indicates that the preparation of the manuscript took place before the author moved to Odessa, while he was teaching Italian at the University of Dorpat. As was the case with Russian Grammar for Italians, this new textbook was based on his practical teaching experience, but unlike the earlier book this new book did not refer to any bibliographic sources. In 1890 the second revised edition of the textbook was published (De Vivo, Prakticheskoe rukovodstvo [1890]), and it was selected by the Russian Imperial Ministry of National Education to be used in the public educational institutions.

In 1894 De Vivo published the first and only volume of his planned twovolume Dizionario Italiano-Russo. Slovar' ital'yansko-russkiy [Italian-Russian dictionary], containing the Italian dictionary translated into Russian. Considered by De Vivo himself to be the first complete Italian-Russian dictionary, this bilingual dictionary represented not only the best tool for cultural-linguistic mediation, but was first and foremost the missing link between Russian Grammar for Italians and A Practical Guide to Learning Italian, supporting and promoting "Russian language learning in Italy and Italian language learning in Russia" (De Vivo, Dizionario V). At the time this dictionary was considered one of the best of its kind, and in 1906 it was still rated by the Ministry of National Education as an essential tool in combination with an Italian textbook ("Utverzhdennaya" 61). Acknowledg- 
ing the typical difficulties for Russian and Italian learners studying L2 grammar, De Vivo paid close attention to the phonetic aspect of the vocabulary, graphically stressing Russian and Italian words in order to ease learners towards acquiring a correct pronunciation. However, De Vivo never seriously considered the new direct methods in the art of L2 teaching.

De Vivo's essay on Comparative Linguistics clearly shows a historicalcomparative approach to analysis within the borders of Indo-European languages. During the 1860 s De Vivo actively participated in Lignana's RUN philological school, where the latter taught 'Comparative Grammar' (or 'Comparative Philology'), which is the original name for 'Comparative Linguistics'. Initially influenced by 'Comparative Linguistics' in Lignana's philological school, De Vivo's approach was certainly different from that of the contemporary leaders of the Reform Movement, such as H. Sweet, P. Passy, and W. Viëtor. His approach was closer to that of the scholars writing or adapting textbooks for learning Russian as L2, such as L. Léger and P. Motti (Reiff and Léger; Motti). To a certain extent, however, De Vivo gave significant consideration to the phonetic aspect of L2 learning. While teaching his students Russian it is likely that he constantly spoke L1, which would then be also used for his Russian grammar for Italians to help the students learn L2 more clearly. All the words in De Vivo's grammar textbooks are stressed (with the exception of the first edition of the Italian textbook). De Vivo begins each work by explaining all the phonetic rules to help the students pronounce the words correctly, because he believed that good pronunciation was the basis for successful L2 acquisition. In some respects, the idea of the primacy of the oral work (especially good pronunciation) in the learning process, is also one of the arguments presented in an almost contemporaneous Lesson plan of the Reform Movement (Howatt and Smith vol. I, XXII-XXIII). The reformers and De Vivo were both influenced by the notion of 'sound laws' promoted in the 1870 s by the Neogrammarians: after 1876, in fact, the thesis of the regularity of the phonetic laws became the central pillar of the etymological science of the Neogrammarians. Both the Neogrammarians and the members of RUN philological school, including De Vivo, began their studies with the analysis of Bopp's ideas on the regularity of 'Lautgesetz'. The Neogrammarians and members of RUN philological school, including De Vivo, had already started to observe the spoken language (in particular dialectal speech) many years before the reformers did. Moreover, Lignana and the members of his philological school had based their opinions on spoken Russian language and 
dialects on the first or second edition of Buslaev's Istoricheskaya grammatika russkogo yazyka [Historical Grammar of the Russian Language]. Since 1840s, Fyodor Buslaev had devoted himself to the study of Bopp's Comparative Grammar and Grimm's Historical Grammar. Representing the new wave of Russian Linguistic scholars, he undertook, with a HistoricalComparative approach, "the task of studying a tongue as a peculiar fact, and the laws behind its evolution" (Vinogradov 72). This explains why De Vivo's approach in the 1880 s was closer to Neogrammarians's and Buslaev's views, than to those of the reformers. The bibliographical reference to the fourth edition of Buslaev's historical grammar book in the footnotes of De Vivo's Russian Grammar for Italians clearly stresses Buslaev influence on De Vivo's conceptions (De Vivo, Grammatica 138).

In the second edition of the Italian textbook, De Vivo devotes more space to the pronunciation of typically Italian voices or sounds, which are usually difficult for Russian learners to pronounce correctly (De Vivo, Prakticheskoe rukovodstvo [1890] II). During the lessons at the New Russia University and at the Odessa Commercial Institute he probably spoke to his students in Italian, but his translation exercises show that he did not consider the direct method at all, while continuing to apply the obsolete GrammarTranslation method. De Vivo's Russian grammar textbook and his Italian textbooks contain greater evidence that the students' L1 was De Vivo's main linguistic point of reference in explaining the L2.

When De Vivo started working at Dorpat University as an Italian language lecturer, he probably used the same Comparative-Historical approach as that used by Lignana for his lessons at RUN philological school. Following this approach, De Vivo published his Comparative-Historical study on Romance verbs (De Vivo, Del futuro). In this case, however, he was influenced not only by the works of Buslaev, but also by the ideas of Yakov Grot. One of the sources for De Vivo's Russian Grammar for Italians was, in fact, the second edition of Grot's Filologicheskie razyskaniya [Philological Research]. In De Vivo's Comparative essay on the Romance languages it is possible to see the same approach of these two celebrated Russian scholars applied to the analysis of the mother tongue through a comparison to the other Romance languages. It is also apparent in the essay that the views of De Vivo are close to those of Grot and Buslaev on the gobetween primary role of the mother tongue for the study of MFL of the same family. The use of a Comparative approach in the advanced level Italian lessons of De Vivo at Dorpat University is therefore certainly feasible. After 
acquiring a good knowledge of the Italian language, the students of Dorpat were finally ready to compare it with the other Romance languages, and they could observe examples of the verbal system of Romance languages in De Vivo's 1882 essay. More formal similarities between the works of Grot and De Vivo are to be found in their L2 learning textbooks. De Vivo's Russian Grammar for Italians (De Vivo, Grammatica), the two editions of the theoretical-practical Italian textbook (De Vivo, Prakticheskoe rukovodstvo [1886 and 1890]), and the Russian-Italian dictionary (De Vivo, Dizionario) were conceived as practical written tools for teaching and learning Russian and Italian. Like Grot, however, De Vivo believed that students could not successfully learn the L2 solely through a classical language learning approach applied via a studied textbook, but that some oral knowledge and practice of the MFL was also necessary for improvement. Though De Vivo's Russian Grammar for Italians does not really show Grot's theoretical-practical approach to L2 teaching, he does openly refer to the phonetics-alphabetical studies contained in Grot's Philological Research. In his Italian textbook for Russian learners he does implicitly refer to Grot's theoretical-practical approach. In fact, he states that the main task of a L2 learning text-book is "to facilitate the practical study of the foreign language by means of briefness and clearness of the exposition of grammatical rules, and with a sufficient number of practical exercises" (De Vivo, Prakticheskoe rukovodstvo [1886] V, and Prakticheskoe rukovodstvo [1890] I). Then he emphasizes the undoubtedly vital roles played in a L2 learning text-book by coherence, continuity, and consistency of exposition. The consistency of the exposition of theoreticalpractical arguments allowed De Vivo to introduce grammatical rules whilst also paying attention to some colloquial aspects of the Italian language. De Vivo was not satisfied with the original order of the topics in the first edition of his textbook - an order which consistently coupled the topics with the exercises. He therefore decided to give the topics a better consistency of exposition, dividing the second edition of the textbook into a first theoretical section and a second practical section. In the theoretical section De Vivo gave a more systematic approach to the presentation and order of the grammatical rules. The grammatical rules were ordered sequentially while in the practical section he arranged all the translation exercises according to the Grammar-Translation method. Nonetheless, the fact that the content of the Grammar-Translation method and some of the practical arguments in translation exercises touched aspects of life needed for commercial, diplomatic, or travel purposes, was closer to Paul Fuchs's approach to teaching than to Grot's views. 
The influence of Fuchs's Grammaire russe à l'usage des français [Russian Grammar for French People] (Fuchs, Grammaire russe; Clef de la Grammaire russe) on Lignana's philological school at RUN is apparent from RUN scholar Gherardo De Vincentiis's letter to the famous Italian philosopher Benedetto Croce on Lignana and De Vivo (ABC, correspondence, 1892, n. 85, G. De Vincentiis to B. Croce, 9.03.1892, 6). Cited by De Vincentiis as an excellent textbook, Fuchs's Russian grammar book applied Ollendorff's method to the study of Russian. Compared to the older approaches to L2 learning, Ollendorff's method facilitated a better understanding and a more effective learning process of the MFL. While Fuchs appreciated the usefulness of MFL learning, he questioned the usefulness of learning classical languages. In contrast to Buslaev and Grot, Fuchs believed that learning classical languages was obsolete and consequently of little use in modern times. According to Fuchs, modern languages were necessary because of their harmonious connection to human life and to the improvements in travel technology: the lower costs and shorter duration of international travel were increasingly favouring the movement of people around the world. Fuchs - whose ideas were shared by De Vivo and Lignana at RAC - believed that the knowledge of MFL was fundamental for commercial, diplomatic, scientific, and industrial purposes at an international level. Fuchs's Russian grammar introduced new elements in Russian grammaticography to French learners, such as graphically stressing all words, and organising the layout of the book in a novel way.

An analysis of De Vivo's Russian Grammar for Italians (De Vivo, Grammatica) demonstrates that this grammar book was intended to be used in L2 learning together with Fuchs's textbook, in line with Ollendorff's method. Applying Ollendorff's original method, De Vivo planned to use his grammar textbook in association with Fuchs's book, recreating the typical two-volume partition, with the only difference being that his grammar textbook is written in Italian and Fuchs's textbook in French. The final reading texts added by De Vivo are placed in the third part of the Russian grammar textbook, occupying almost a fifth of the entire book. Except for four fantasy tales and three historical stories, the subject matter of the readings does not concern literature, but mainly biology and earth sciences, offering students a more practical topic for practicing the Russian language. A point that is worthy of note is that only three years later after the publication of De Vivo's Russian grammar text H. Sweet's Elementarbuch des gesprochenen Englisch [A Primer of Spoken English] (Sweet), which was divided 
into a grammar section, a texts section and an English-German glossary section, contained some short descriptive texts also regarding topics on nature, anthropology, and history.

Nevertheless, if De Vivo's Russian Grammar for Italians (De Vivo, Grammatica) is mainly a theoretical descriptive handbook, De Vivo's A Practical Guide to Learning Italian (De Vivo, Prakticheskoe rukovodstvo [1886 and 1890]) is a more theoretical-practical handbook, applying Grot's approach and at the same time following the Grammar-Translation method. In the theory and practice of language learning, De Vivo took into consideration the gradual nature of L2 learning. Theory and practical translation exercises are deeply related to each other. However, although he provides examples or translation sentences of questions and answers, these questions and answers are never put into a series. Therefore, the typical Ollendorffian conversational-practical interaction is missing. The Italian scholar preferred to insert disconnected translation sentences to illustrate specific grammar rules to the learners. He also included entire passages of famous Russian and Italian writers as translation exercises. In this approach it is possible to see a return to older methods of language learning, such as those of J. Seidenstücker and K. Plötz. The students, in fact, had to translate sets of disconnected sentences placed one after the other - which represented the opposite of Sweet's approach of employing connected texts (Howatt and Smith vol. II, XXVIII). Therefore, such disconnected sentences in various stages of translation from L2 into L1 or L1 into L2 were used for L2 presentation from the beginning in order to demonstrate L2 grammar as a didactic study. It is apparent that this approach certainly does not take into account the principles of the Reform Movement, already presented in the September 1886 issue of The Phonetic Teacher by P. Passy (Howatt and Smith vol. II, XXXIX).

In conclusion, De Vivo's main didactic approach to teaching Russian is purely deductive: speaking L1 to the students, he introduced the grammar rules of L2, which were then practiced by the students through translation exercises. Therefore, the explanation of the grammar, the memorization of the vocabulary, and the translation of sentences were the basic units of De Vivo's lessons. As an Italian teacher De Vivo was appreciated by his contemporaries in Odessa, so he certainly succeeded in teaching the Italian language to non-Italian students at the University of New Russia and at the Commercial High School of Odessa. Later, in 1906, almost ten years after his death, his Russian grammar textbook, his Italian textbook and his Russian-Italian dictionary were exhibited at the Milan fair dedicated to Italians 
abroad. Thanks to the exhibition of these works he received a post mortem note of merit among those Italians abroad who distinguished themselves in the sciences and belles-lettres (Frescura 192). His method was also eventually officially recognized in Italy, but this only took place years after his death. This belated period of posthumous recognition did not last long and afterwards the publishing industry lost interest in De Vivo's works, focusing on works of contemporary living scholars.

\section{BIBLIOGRAPHY}

Buslaev, Fyodor I. Istoricheskaya grammatika russkogo yazyka, Moskva, 1863 [Буслаев, Фёдор И. Историческая грамматика русского языка. Москва, 1863].

Buslaev, Fyodor I. Istoricheskaya grammatika russkogo yazyka. V 2-kh tomakh. Moskva, 18681869 [Буслаев, Фёдор И. Историческая грамматика русского языка. В 2-х томах. Москва, 1868-1869].

Buslaev, Fyodor I. Istoricheskaya grammatika russkogo yazyka. V 2-kh tomakh. Moskva, 1875 [Буслаев, Фёдор И. Историческая грамматика русского языка. В 2-х томах. Москва, 1875.].

Buslaev, Fyodor I. Opyt istoricheskoy grammatiki russkogo yazyka. Moskva, 1858 [Буслаев, Фёдор И. Опыт исторической грамматики русского языка. Москва. 1858].

Cifariello, Alessandro. "Domenico De Vivo: tra russistica e italianistica nella seconda metà dell'Ottocento". Russica Romana, no. 24, 2017, pp. 47-72.

Cifariello, Alessandro. “L'insegnamento della lingua russa nell'Università italiana dal 1864 al 1892”. Italiano Lingua Due, no. 1, 2018, pp. 149-167.

Cifariello, Alessandro. "La grammaticografia della lingua russa in italiano (1882-1917)". Lingue seconde e istituzioni. Un approccio storiografico, ed. A. Vicentini and H. E. Lombardini, CLUEB, 2019, pp. 49-69.

Cifariello, Alessandro. "O pervoy russkoy grammatike na ital'yanskom yazyke”. Uchënye zapiski Petrozavodskogo gosudarstvennogo universiteta, no. 7 (168), 2017, ss. 96-103 [Чифариелло, Алессандро. “О первой русской грамматике на итальянском языке”. Ученые записки Петрозаводского государственного университета, № 7 (168), 2017, сc. 96-103].

Croce, Benedetto. "Schizzi biografici. I. Giacomo Lignana”. Pagine sparse. Ricciardi, 1920, pp. 65-85.

De Vivo, D. Prakticheskoe rukovodstvo dlya izucheniya ital'yanskogo yazyka. Odessa, 1886 [Де Виво, Доменико. Практическое руководство для изучения итальянского языка. Одесса, 1886].

De Vivo, D. Prakticheskoe rukovodstvo dlya izucheniya ital'yanskogo yazyka. Odessa, 1890 [Де Виво, Доменико. Практическое руководство для изучения итальянского языка. Одесса, 1890].

De Vivo, Domenico. Del futuro e del condizionale nell'Italiano in rapporto colle altre lingue romanze. Dorpat, 1882.

De Vivo, Domenico. Dizionario Italiano-Russo. Slovar' ital'yansko-russkiy. Odessa, 1894. 
De Vivo, Domenico. Grammatica della lingua russa. Con speciale attenzione al movimento dell'accento. Dorpat, 1882.

Fatica, Michele. "Breve storia dell'Università degli Studi di Napoli 'L'Orientale'”. Le università del Mezzogiorno nella storia dell'Italia unita, 1861-2011, edited by A. Bianchi, Il mulino, 2011, pp. 237-251.

Fatica, Michele. "Giacomo Lignana, Michele Kerbaker, Angelo De Gubernatis e la fondazione a Napoli dell'Istituto Orientale (1888)". Scritture di storia, no. 4, 2005, pp. 165-230.

Frescura, Bernardino. La Mostra Gli Italiani all'estero, all'Esposizione Internazionale di Milano nel 1906. G. Bertero, 1907.

Fuchs, Paul Grammaire russe à l'usage des français. Francfort, 1865.

Fuchs, Paul. Clef de la Grammaire russe à l'usage des français. Francfort, 1865.

Fuchs, Paul. Clef de la Grammaire russe à l'usage des français. Francfort, 1874.

Fuchs, Paul. Grammaire russe à l'usage des français. Francfort, 1874.

Gretsch, Nikolay I., and Charles-Philippe Reiff. Grammaire raisonnée de la langue russe, 2 vols, Paris, 1828-1829.

Grot, Yakov K. Filologicheskie razyskaniya. Materialy dlya slovarya, grammatiki i istorii russkogo yazyka, V 2-kh tomakh, Sankt-Peterburg, 1876 [Грот, Яков К. Филологические разыскания: Материаль для словаря, грамматики и истории русского языка. В 2-х томах. Санкт-Петербург, 1876].

Howatt, Anthony P. R., and Richard C. Smith. Modern Language teaching. The reform movement, 5 vols, Routledge, 2002.

Istoricheskiy ocherk 50-letiya Odesskogo kommercheskogo uchilishcha. 1862-1912. tsentr. tip. N. Lemberga i S. Rosenshtraukha, 1912 [Исторический очерк 50-летия Одесского коммерческого училища. 1862-1912. центр. тип. Н. Лемберга и С. Розенштрауха, 1912].

Lignana, Giacomo. Relazione del commissario speciale prof. Lignana Giacomo a S. E. il Ministro della pubblica istruzione sul Regio Collegio Asiatico di Napoli e documenti relative. Roma, 1881.

Motti, Pietro. Petite grammaire russe. Methode Gaspey-Otto-Sauer. Heidelberg, 1898.

Pavskiy, G.P. Filologicheskie nablyudeniya nablyudeniya protoiyereya G. Pavskogo nad sostavom russkogo yazyka: Rassuzhdeniye 1-3. Sankt-Peterburg, 1841 [Павский, Герасим П. Филологические наблюдения протоиерея Г. Павского над составом русского языка: Рассуждение 1-3. Санкт-Петербург, 1841].

Reiff, Charles-Philippe, and Louis Léger. Grammaire russe avec des tableaux synoptique pour les déclinaisons et les conjugaisons des thèmes ou exercices gradués, le corrigé de ces exercices et l'accentuation de tous les mots russes, revue corrigé et augmentée par Louis Léger. Paris, 1886.

Spisok lits, sluzhashchikh po vedomstvu Ministerstva narodnogo prosveshcheniya na 1879/80 uchebnyy god. Sankt-Peterburg, 1879 [Список лии, служащих по ведомству Министерства народного просвещения на 1879/80 учебный год. Санкт-Петербург, 1879].

Sweet, Henry. Elementarbuch des gesprochenen Englisch (Grammatik, Texte und Glossar). Oxford, 1885.

"Utverzhdënnaya Ministerstvom narodnogo prosveshcheniya programma ispytaniya na zvanie uchitelya gimnazii po ital'yanskomu yazyku". Zhurnal Ministerstva narodnogo prosveshcheniya, 6 (12), 1906 ["Утвержденная Министерством народного просвещения 
программа испытания на звание учителя гимназии по итальянскому языку”. Журнал Министерства народного просвещения, VI (12), 1906].

Varvartsev, Mykola. Italiytsi v kul'turnomuprostori Ukrayiny (kinets' XVIII - 20-ti rr. XX st.). Istoryko-byohrafichne byohrafichne doslidzhennya. In-t istoryii Ukrainy NAN Ukrainy, 2000 [Варварцев, Микола. Італійці в культурному просторі України (кінець XVIII 20-mi pp. ХХ ст.). Історико-биографічне дослідження. Ін-т істориіі Украіни НАН Украіни, 2000].

Vinogradov, Viktor V. Istoriya russkikh lingvisticheskikh ucheniy. Vysshaya shkola, 1978 [Виноградов, Виктор В. История русских лингвистических учений. Высшая школа, 1978].

Voinovich, Prof. Grammatica della lingua russa. Milano, 1897.

Vostokov, Aleksandr Kh. Russkaya grammatika. Sankt-Peterburg, 1874 [Востоков Александр Х. Русская грамматика. Санкт-Петербург, 1874].

\section{ROLA DOMENICO DE VIVO \\ W ROZWOJU FILOLOGII ROSYJSKIEJ I WŁOSKIEJ W DRUGIEJ POŁOWIE XIX WIEKU}

\section{Streszczenie}

O Domenico De Vivo (1839-1897) wiadomo niewiele. Był uczniem włoskiego lingwisty Giacomo Lignany. Pracował jako profesor języka rosyjskiego i angielskiego w Asiatic College w Neapolu w latach 1868-1870, a następnie - od 1879 aż do śmierci w 1897 r. - jako wykładowca języka włoskiego na uniwersytetach w Dorpacie i Odessie w Cesarstwie Rosyjskim. De Vivo bronił swoich pomysłów dotyczących nauczania i uczenia się języków w swoich książkach Grammatica della lingua russa [Gramatyka języka rosyjskiego dla Włochów] (Dorpat, 1882) i Prakticheskoe rukovodstvo dlya izucheniya ital'yanskogo yazyka [Praktyczny przewodnik do nauki języka włoskiego] (Odessa, 1886; Odessa, 1890), a także w Dizionario Italiano-Russo. Slovar' ital'yansko-russkiy [Słownik włosko-rosyjski] (Odessa 1894). Celem niniejszego artykułu jest zbadanie życia i twórczości De Vivo, stanowiących pierwszą zarejestrowaną próbę - według jego własnych słów - ,promowania nauki języka rosyjskiego we Włoszech i nauki języka włoskiego w Rosji”.

Słowa kluczowe: historia; rusycystyka; filologia włoska; Odessa; Neapol.

\section{THE ROLE OF DOMENICO DE VIVO \\ IN DEVELOPING RUSSIAN AND ITALIAN LANGUAGE STUDIES IN THE SECOND HALF OF 19TH CENTURY}

\section{S u m mary}

Very little is known about Domenico De Vivo (1839-1897). He was a disciple of the Italian linguist Giacomo Lignana and worked as a professor of Russian and English language at the Asiatic College in Naples from 1868 to 1870, and then as an Italian language lecturer at the universities of Dorpat and Odessa in the Russian Empire from 1879 until his death in 1897. De Vivo championed his ideas on language teaching and learning in his books Grammatica della lingua russa [Russian Grammar for Italians] (Dorpat, 1882) and Prakticheskoe rukovodstvo dlya 
izucheniya ital'yanskogo yazyka [A Practical Guide to Learning Italian] (Odessa, 1886; Odessa, 1890), and in his Dizionario Italiano-Russo. Slovar' ital'yansko-russkiy [Italian-Russian Dictionary] (Odessa 1894). The purpose of this article is to examine De Vivo's life and works, which represent the first recorded attempt - in De Vivo's own words - "to promote Russian language learning in Italy and Italian language learning in Russia."

Keywords: history; Russian studies; Italian studies; Odessa; Naples. 